\title{
Pemodelan dan Simulasi Penyebaran Penyakit Demam Berdarah Dengue (DBD) dengan Menggunakan Model Cellular Automata
}

\author{
Olivia. Hasan, Steven R. Sentinuwo, Alwin M. Sambul \\ Teknik Informatika Universitas Sam Ratulangi. Manado \\ Jl. Kampus UNSRAT Bahu, 95115 \\ 110216155@student.unsrat.ac.id, steven@unsrat.ac.id, asambul@unsrat.ac.id
}

\begin{abstract}
Abstrak - Demam Berdarah Dengue (DBD) merupakan salah satu masalah kesehatan masyarakat di Indonesia. Penyakit demam berdarah sering terjadi di daerah tropis dikarenakan nyamuk pembawa virus terdapat hampir di seluruh pelosok Indonesia khususnya daerah yang beriklim tropis. Kota Manado merupakan salah satu daerah yang endemik untuk kasus demam berdarah, jumlah kasus DBD di kota Manado hampir setiap tahunnya meningkat. Melihat realita kasus DBD yang terjadi, maka perlu adanya kerja sama dari semua elemen baik dari masyarakat umum, pelayanan kesehatan, dunia pendidikan dan pemerintah untuk bersama-sama mencegah terjadinya wabah demam berdarah dilingkungan sekitar tempat tinggal. Penelitian ini akan membahas tentang perkembangan penyakit DBD di kota Manado pada tahun 2011 - 2014, sehingga dari hasil penelitian tersebut menghasilkan sebuah aplikasi yang dapat menjalankan simulasi penyebaran penyakit DBD pada tahun 2011 - 2014 di kota Manado. Aplikasi tersebut bermanfaat untuk memberikan informasi tentang perkembangan kasus DBD tahun 2011 - 2014 pada 9 kecamatan yang ada di kota Manado.
\end{abstract}

Kata kunci : DBD, Aedes Aegpti, Endemik, Virus. Simulasi, Cellular Automata. Range.

\section{PENDAHULUAN}

Demam berdarah di sebabkan oleh virus dengue yang ditularkan ke peredaraan darah manusia melalui gigitan nyamuk Aedes aegypti. Nyamuk penularan virus dengue terdapat hampir di seluruh pelosok Indonesia, kecuali di tempat yang memiliki ketinggian lebih dari 100 meter di atas permukaan laut dan sering dijumpai di daerah tropis. Faktor yang mempengaruhi munculnya virus dengue antara lain besarnya jumlah kepadatan penduduk di suatu pemukiman, lingkungan pemukiman dan gaya hidup masyarakat yang tidak sehat

Kota Manado merupakan salah satu daerah endemik untuk kasus demam berdarah tertinggi di Sulawesi Utara. Data terakhir yang diperoleh dari Surveilans Dinas Kesehatan Provinsi Sulawesi Utara jumlah kasus Demam Berdarah Dengue (DBD) di kota Manado yaitu 72 penderita 1 diantaranya meningal Melihat realita kasus DBD yang terjadi, maka perlu adanya kerja sama dari semua elemen baik dari masyarakat umum, pelayanan kesehatan, dunia pendidikan dan pemerintah untuk bersama-sama mencegah terjadinya wabah demam berdarah dilingkungan sekitar tempat tinggal.

Seiring dengan perkembangan teknologi perlu adanya sebuah sistem komputer yang bertujuan untuk memberikan informasi kepada masyarakat tentang perkembangan penyakit di daerah sekitar tempat tinggal. Terkait dengan penelitian yang akan dilakukan, maka penulis akan membuat sebuah simulasi penyebaran DBD.

Pada proses simulasi diawali dengan pembangunan model sistem nyata, dimana model tersebut harus dapat menunjukkan bagaimana suatu komponen - komponen dalam sistem saling berinteraksi sehingga benar- benar bisa menggambarkan perilaku sistem. Model yang akan digunakan pada pembuatan simulasi yaitu model Cellular Automata (CA).

Cellular Automata (CA) awalnya diperkenalkan oleh Jhon Von Neuman dan Stain Slaw Marchin Ulam dengan nama cellular space pada tahun 1948 sebagai model sederhana untuk menyelidiki perilaku sistem kompleks secara luas dan mempelajari proses biologis.

Dari hasil data yang diperoleh maka penulis akan membuat model simulasi penyebaran penyakit Demam Berdarah DBD di kota Manado dengan menerapkan model Cellular Automata.

Penelitian ini akan menghasilkan aplikasi untuk memberikan informasi tentang perkembangan kasus Demam Berdarah Dengue (DBD) pada 9 Kecamatan yang ada di kota Manado sesuai dengan data pada tahun $2011-2014$.

\section{LANDASAN TEORI}

A. Pemodelan dan Simulasi

simulasi merupakan suatu teknik meniru kondisi, sifat, atau karakter dari lingkungan nyata ke dalam sebuah model. Istilah pemodelan dan simulasi sering dikaitkan juga dengan pemanfaatan sumber daya komputer untuk menggambarkan sistem dunia nyata 
ke dalam sebuah model matematika, logika, atau statistika (Steven,2015).

Pendekatan simulasi diawali dengan pembangunan model sistem nyata. Model tersebut harus dapat menunjukkan bagaimana berbagai komponen dalam sistem saling berinteraksi sehingga benar-benar menggambarkan perilaku sistem. Setelah model dibuat maka model tersebut ditransformasikan ke dalam program komputer sehingga memungkinkan untuk disimulasikan (Steven, 2015).

Law and Kelton mengklasifikasikan model simulasi ke dalam 3 dimensi yaitu:

a) Model simulasi statis dan model simulasi dinamis.Simulasi statis digunakan untuk mempresentasikan sistem pada saat tertentu atau sistem yang tidak terpengaruh oleh perubahan waktu, sedangkan model simulasi dinamis yaitu model simulasi yang digunakan jika sistem yang dikaji di pengaruhi oleh perubahan waktu.

b) Model simulasi deterministik dan model simulasi stokastik.Simulasi deterministik merupakan model simulasi yang akan dibentuk tidak mengandung variabel yang bersifat random. Sedangkan model simulasi stokastik merupakan model simulasi yang memiliki beberapa variable random dalam inputannya.

c) Model simulasi Kontinu dan Model Simulasi Diskrit.Model simulasi kontinu merupakan model simulasi yang status variabelnya berubah secara berkelanjutan seiring dengan perubahan waktu, sedangkan model simulasi diskrit sistem dikatakan diskrit jika variabel sistem yang mencerminkan status sistem berubah pada titik waktu tertentu.

Law dan Kelton menjelaskan beberapa keuntungan menggunakan simulasi adalah sebagai berikut :

a) Memiliki fleksibilitas yang besar dalam memodelkan suatu sistem yang kompleks, sehingga meningkatkan keabsahan dari suatu model simulasi.

b) Memudahkan dalam perbandingan dengan alternatifalternatif lain.

c) Kondisi dalam eksperimen yang dapat dikontrol - Sistem dapat dipelajari dalam jangka waktu yang lama.

d) Dapat mengontrol skala waktu.
B. Cellular Automata (CA)

Cellular Automata pertama kali diperkenalkan oleh John Von Neuman dan Stain Slaw Marchin Ulam dengan nama awal cellular space pada tahun 1948, sebagai idealisasi sistem biologi. Ulam dan von Neuman menggunakan. Cellular Automata sebagai dasar untuk menyelediki fenomena yang bersifat kompleks (Suwarna, 2005).

Cellular Automata (CA) juga merupakan suatu model dari sistem fisik dimana ruang dan waktu adalah diskrit dan interaksi yang terjadi bersifat lokal. Disamping kesederhanaan strukturnya, CA juga dapat digunakan untuk memperlihatkan fenomena kompleks yang dinamis dan dapat menerangkan berbagai macam proses dan sistem fisik. Model CA terdiri dari satu, dua atau n-dimensi array yang terdiri dari sel-sel seragam dan tetap. Model CA yang sering digunakan yaitu model satu dan dua dimensi dikarenakan model CA dengan dimensi yang lebih tinggi kesulitan dalam memvisualisasinya (Steven, 2015).

Unsur-unsur pembentuk Cellular Automata (Syopiansyah, 2008) meliputi :

a) Geometry

Geometri CA terdiri atas dimensi CA tersebut dan bentuk geometri dari masingmasing sel penyusunnya.

b) State SetState Set merupakan himpunan status atau keadaaan yang dimiliki oleh masing - masing sel CA. Status dapat berupa angka atau sifat tertentu.

c) Neighbourhood

Neighbourhood merupakan ketetanggaan antara sel dalam CA, neighbour dapat mempengaruhi status suatu sel pada CA. Umumnya neighbourhood suatu sel menjangkau sel-sel yang berada di sekitarnya..

C. Demam Berdarah Dengue (DBD)

Demam berdarah merupakan penyakit yang disebabkan oleh virus dengue yang tergolong arbovirus yang ditularkan ke peredaraan darah manusia melalui gigitan nyamuk Aedes aegypti. Nyamuk penularan virus dengue terdapat hampir di seluruh pelosok Indonesia, kecuali di tempat yang memiliki ketinggian lebih dari 100 meter di atas permukaan laut dan sering dijumpai di daerah tropis. Penyebaran penyakit demam berdarah di negara Indonesia semakin meluas, hingga saat ini Indonesia menempati urutan kedua terbesar setelah Thailand dengan jumlah penderita dan tingkat kematian yang tinggi akibat penyakit demam berdarah (Zulaikhah, 2014).

Faktor kepadatan penduduk dapat meningkatkan penularan kasus DBD, dimana semakin banyak populasi manusia maka akan semakin besar peluang nyamuk aedes aegypti menggigit. Sehingga 
penyebaran kasus DBD dapat menyebar dengan cepat dalam suatu wilayah (Claudia, 2015).

D. Javascript

Javascript merupakan bahasa scripting yang digunakan untuk membuat aplikasi web, sifatnya client-side sehingga dapat diolah langsung di browser tanpa harus terhubung keserver terlebih dahulu. Kegunaan utama dari JavaScript adalah untuk menuliskan fungsi yang disisipkan kedalam HTML baik secara langsung disisipkan maupun diletakan ke file teks dan di link dari dokumen HTML (Indra, 2014).

\section{E. Hyper Text Merkup Laguage (HTML5)}

HTML5 adalah generasi terbaru setelah HTML sebagai generasi penerus HTML 4.01, XHTML 1.0, dan XHTML 1.1. HTML5 dirancang sebagai bahasa yang cross-platform, penggunaannya tidak didasarkan pada platform dimana HTML5 itu sendiri berjalan. Yang dibutuhkan untuk memanfaatkan fitur-fiturnya hanyalah sebuah peramban web yang modern (Anggi, 2014).

\section{F. Cascading Style Sheet (CSS).}

CSS merupakan sebuah bahasa berbasis teks yang digunakan untuk memformat tampilan dari halaman web yang dibuat pada HTML. CSS juga dapat mengendalikan ukuran gambar, warna teks, warna tabel, ukuran border, warna border, warna hyperlink, warna mouse over, spasi antar paragraf, spasi antar teks, margin kiri, kanan, atas, bawah, dan parameter lainnya. Jika HTML digunakan untuk membuat struktur Web maka CSS digunakan untuk mempercantik tampilan web (Arif, 2012).

\section{METODOLOGI PENELITIAN}

\section{A. Kerangka Kerja}

Untuk membuat sebuah penelitian dibutuhkan kerangka kerja agar penelitian yang akan dilakukan dapat berjalan dengan baik. Kerangka kerja dapat dilihat pada gambar dibawah ini.

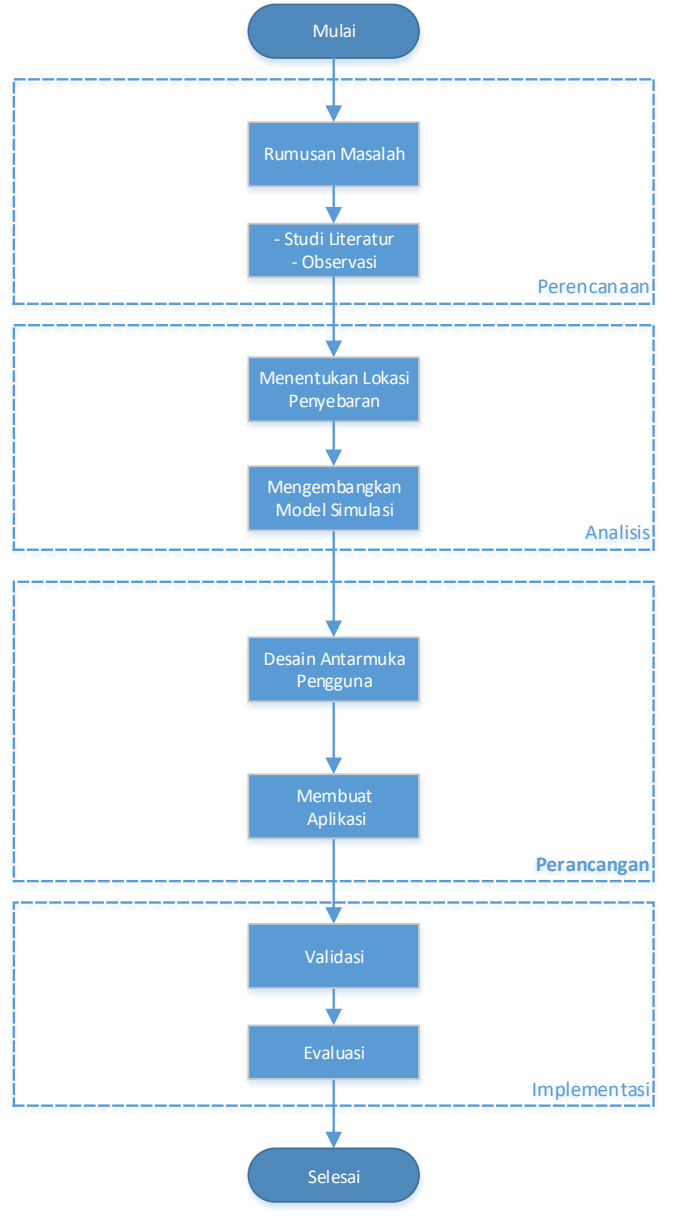

Gambar 1. Kerangka Kerja

B. Analisa Data

Data yang digunakan pada penelitian ini yaitu data DBD pada tahun 2011 - 2014 yang diambil dari Dinas Kesehatan kota Manado. Setelah itu penulis merangkum data yang ada untuk digunakan pada pada proses pembuatan simulasi. Data yang akan digunakan dapat dilihat pada tabel dibawah ini. 


\begin{tabular}{|c|c|c|c|c|c|c|c|c|}
\hline \multirow{2}{*}{ KECAMATAN } & \multicolumn{4}{|c|}{ TAHUN } & \multicolumn{4}{|c|}{ RANGE ANGKA DAN WARNA } \\
\hline & 2011 & 2012 & 2013 & 2014 & 2011 & 2012 & 2013 & 2014 \\
\hline \multirow[t]{2}{*}{ Bunaken } & 0 & 11 & 6 & 21 & $<100$ & $<100$ & $<100$ & $<100$ \\
\hline & & & & & Hijau & Hijau & Hijau & Hijau \\
\hline \multirow[t]{2}{*}{ Sario } & 5 & 98 & 24 & 59 & $<100$ & $<100$ & $<100$ & $<100$ \\
\hline & & & & & Hijzu & Hijau & Hijau & Hijeu \\
\hline \multirow[t]{2}{*}{ Wenang } & 4 & 63 & 29 & 29 & $<100$ & $<100$ & $<100$ & $<100$ \\
\hline & & & & & Hijau & Hijus & Hijau & Hijau \\
\hline \multirow[t]{2}{*}{ Wanea } & 25 & 170 & 43 & 61 & $<100$ & $>100$ & $<100$ & $<100$ \\
\hline & & & & & Hijau & Merah & Hijau & Hijeu \\
\hline \multirow[t]{2}{*}{ Tikala } & 2 & 179 & 31 & 56 & $<100$ & $>100$ & $<100$ & $<100$ \\
\hline & & & & & Hijau & Merah & Hijau & Hijau \\
\hline \multirow[t]{2}{*}{ Mapanget } & 8 & 100 & 63 & 65 & $<100$ & $>100$ & $<100$ & $<100$ \\
\hline & & & & & Hijau & Hijwu & Hijzu & Hijau \\
\hline \multirow[t]{2}{*}{ Singkil } & 244 & 80 & 71 & 107 & $>100$ & $<100$ & $<100$ & $>100$ \\
\hline & & & & & Merah & Hijwu & Hijau & Merah \\
\hline \multirow[t]{2}{*}{ Tuminting } & 78 & 84 & 52 & 35 & $<100$ & $<100$ & $<100$ & $<100$ \\
\hline & & & & & Hijzzu & Hijau & Hijau & Hijeu \\
\hline \multirow[t]{2}{*}{ Malalayang } & 42 & 212 & 91 & 84 & $<100$ & $>100$ & $<100$ & $<100$ \\
\hline & & & & & Hijau & Merah & Hijau & Hijeu \\
\hline
\end{tabular}

Tabel 1. Data yang digunakan pada simulasi

\section{Peta lokasi penyebaran}

Peta lokasi penyebaran merupakan peta yang akan tampil ketika akan menjalankan simulasi. Pertama tama aplikasi akan menampilkan peta lokasi penyebaran meliputi kecamatan Bunaken, Mapanget, Singkil, Wenang, Sario, dan Malalayang dari tahun 2011 - 2014. Tampilan Peta lokasi penyebaran pada saat menjalankan simulasi dapat dilihat pada gambar dibawah ini :

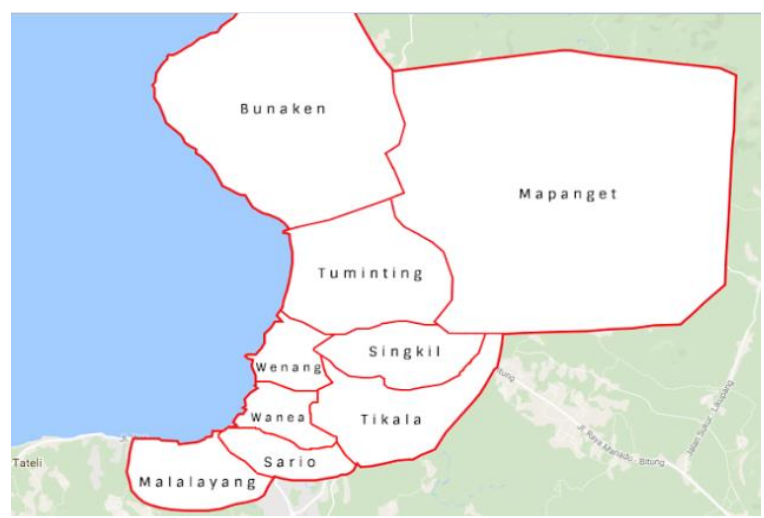

Gambar 2. Lokasi penyebaran

D. Range angka dan warna

Range angka dan warna merupakan skala angka dan warna yang ditentukan pada proses pembuatan simulasi. Berfungsi untuk menentukan tinggi atau rendahnya suatu kasus DBD ditiap lokasi penyebaran.

\begin{tabular}{|c|c|}
\hline Range Angka & Range Warna \\
\hline$>100$ & Merah \\
\hline$<100$ & Hijau \\
\hline
\end{tabular}

Tabel 2. Range angka dan warna

Tabel 2 diatas menjelaskan bahwa jumlah kasus DBD ditiap kecamatan yang jumlah kasusnya lebih dari 100 penderita, maka pada saat menjalankan simulasi daerah tersebut akan berwarna Merah, sedangkan jumlah kasus ditiap kecamatan yang jumlah kasus DBD dibawah 100 maka daerah tersebut akan berwarna Hijau.

\section{E. Pixel Warna}

Pixel warna merupakan objek yang akan tampil pada simulasi. Setelah sistem menampilkan peta lokasi penyebaran, selanjutnya pixel warna berbentuk kotak perlahan - lahan akan mengisi area penyebaran sesuai dengan range warna yang sudah ditentukan di tiap kecamatan. Ada dua jenis pixel warna yang akan tampil pada simulasi yaitu pixel berwarna Merah mewakili jumlah kasus $>100$, sedangkan pixel berwarna Hijau mewakili jumlah kasus < 100. Gambar 3 dibawah ini merupakan pixel warna yang dimaksud.

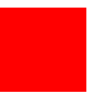

Gambar 3.Pixel warna

\section{F. Perancangan Sistem}

Secara garis besar perancangan sistem dapat dilihat pada gambar dibawah ini. 


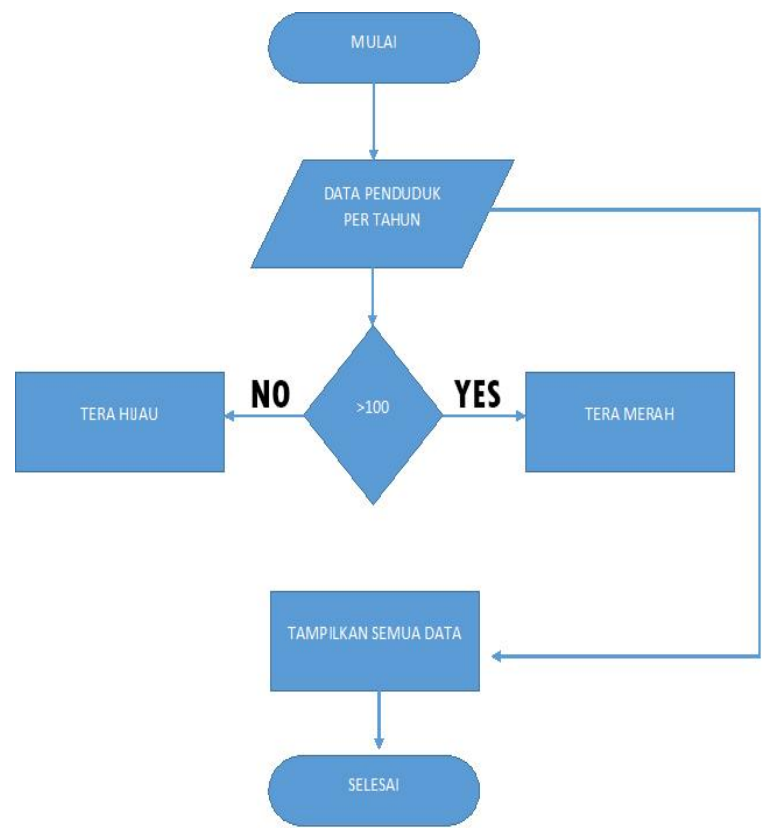

Gambar 4. Alur kerja sistem

Alur Kerja pada Sistem secara garis besar dapat dijelaskan bahwa :

a) Data penduduk merupakan tahap pertama ketika user akan menjalankan simulasi, dimana data yang akan dipakai pada simulasi di hitung agar bisa dikonferiskan ke terra. Terra merupakan salah satu librray javascript yang dipakai penulis untuk menjalankan simulasi pada sistem.

b) Selanjutnya dari hasil data yang sudah di konfersikan ke terra, dimana data penderita DBD ditiap kecamatan yang jumlah kasusnya > 100 akan mendapatkan hasil terra berwarna Merah pada sistem.

c) Sedangkan data penderita DBD yang jumlah kasusnya $<100$ akan mendapatkan hasil terra berwarna Hijau pada sistem.

d) Pada tahap yang terakhi yaitu sistem akan menampilkan hasil jumlah keseluruhan data.

\section{HASIL DAN PEMBAHASAN}

A. Tampilan Aplikasi

Setelah melalui proses pengumpulan dan perancangan selesai maka dari proses tersebut menghasilkan aplikasi yang didalamnya memiliki fitur - fitur untuk menjalankan simulasi. Berikut tampilan aplikasi yang berhasil dibuat.
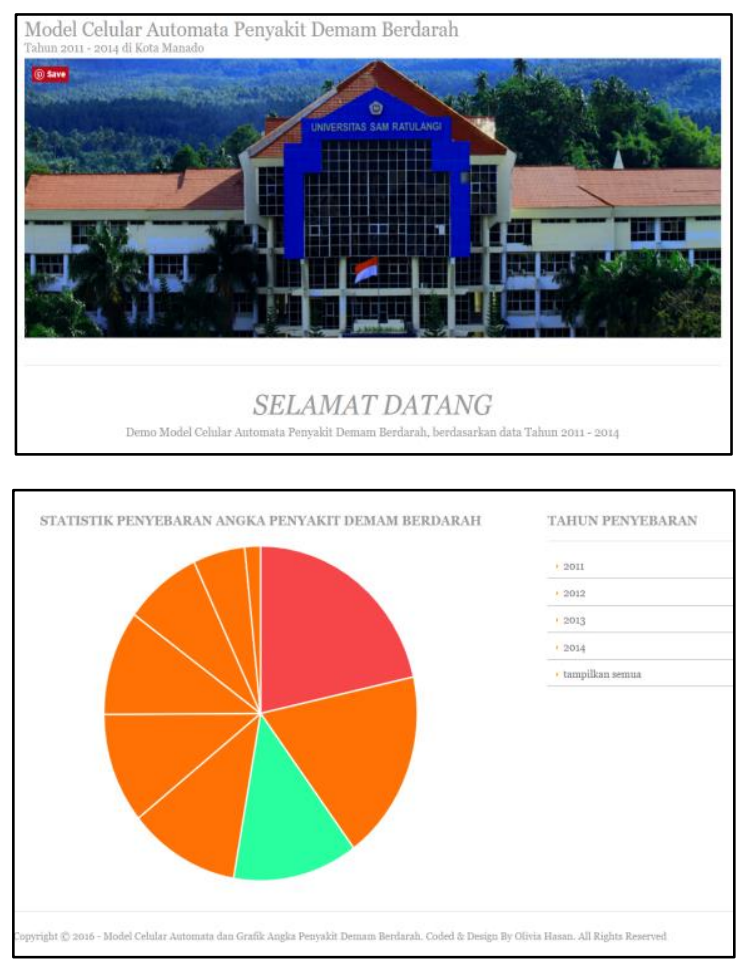

Gambar 5. Tampilan aplikasi

Gambar 3. di atas merupakan tampilan aplikasi dari hasil penelitian, dapat dilihat pada tampilan sebelah kiri menampilkan chart berbentuk lingkaran yang berfungsi untuk menampilkan total jumlah keseluruhan data di 9 kecamatan di kota manado. Kemudian pada tampilan sebelah kanan menampilkan lima form yang berfungsi sebagai fitur untuk menampilkan simulasi.

B. Tampilan Aplikasi

Hasil simulasi yang ditampilkan pada aplikasi dapat dilihat pada gambar dibawah ini.

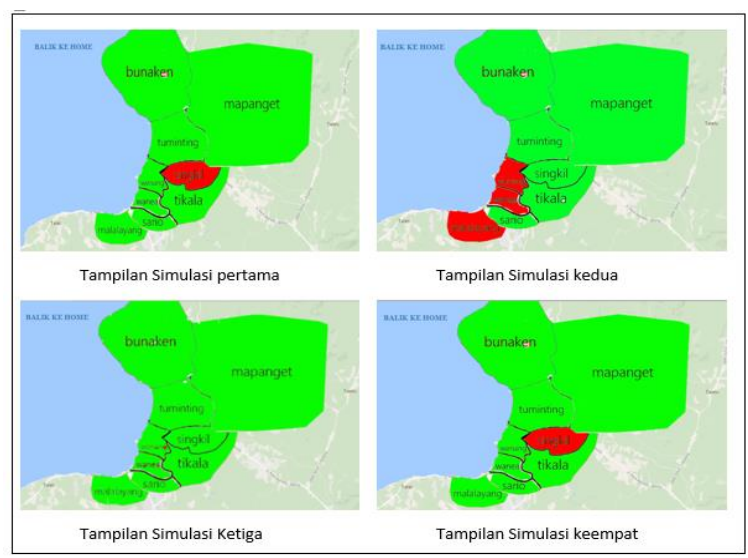

Gambar 6. Hasil simulasi yang ditampilkan

a) Tampilan Simulasi pertama merupakan tampilan hasil simulasi pada tahun 2011 yang ditampilkan oleh sistem. Dari hasil simulasi 
tersebut dapat menunjukan bahwa daerah yang endemik untuk kasus demam berdarah di tahun 2012 berada di kecamatan Singkil.

b) Tampilan Simulasi kedua merupakan tampilan hasil simulasi pada tahun 2012 yang ditampilkan oleh sistem. Dari hasil simulasi tersebut dapat menunjukan bahwa daerah yang endemik untuk kasus demam berdarah di tahun 2012 berada di kecamatan Wenang, Wanea, dan Malalayang.

c) Tampilan Simulasi ketiga merupakan tampilan hasil simulasi pada tahun 2013 yang ditampilkan oleh sistem. Hasil simulasi tersebut dapat menunjukan bahwa pada tahun 2013 tidak ada daerah yang endemik untuk kasus demam.

d) Tampilan Simulasi pertama merupakan tampilan hasil simulasi pada tahun 2014 yang ditampilkan oleh sistem. Dari hasil simulasi tersebut dapat menunjukan bahwa daerah yang endemik untuk kasus demam berdarah di tahun 2014 berada di kecamatan Singkil. Sehingga dari hasil simulasi keseluruhan dapat disimpulkan bahwa pada tahun 2011 sampai dengan tahun 2014 virus dengue menyebar ke arah bagian Barat disesuaikan dengan peta lokasi

\section{KESIMPULAN DAN SARAN}

A. Kesimpulan

Kesimpulan akhir dari pembuatan tugas akhir Pemodelan dan Simulasi Penyebaran penyakit Demam Berdarah Dengue (DBD) dengan menggunakan model Cellular Automata adalah sebagai berikut:

a) Simulasi penyebaran penyakit demam berdarah pada 9 kecamatan di kota Manado berhasil dibuat dengan menggunakan library terra.js sebagai model Cellular Automata (CA) memanfaatkan warna pada terra sebagai sel, sedangkan gambar peta sebagai grid. Simulasi tersebut dibuat menggunakan bahasa pemrograman web.

b) Dengan menampilkan Hasil Simulasi tersebut dapat dilihat bahwa penyakit DBD pada tahun 2011 - 2014 menyebar ke arah bagian Barat disesuaikan dengan peta lokasi penyebaran.

c) Dari hasil penelitian dapat dilihat bahwa daerah yang endemik untuk kasus demam berdarah pada tahun 2011 - 2014 di kota Manado yaitu pada kecamatan Singkil.

B. Saran

Saran yang dapat penulis sampaikan yaitu : a) Untuk penelitian selanjutnya sebaiknya data yang dikumpulkan lebih lengkap agar tidak kesulitan dalam proses pengolahan data.

b) Penelitian selanjutnya diharapkan lebih luas dalam mengembangkan model Cellular Automata.

c) Pengembangan selanjutnya diharapkan agar dapat membuat sistem untuk prediksi kasus Demam Berdarah Dengue (DBD) di kota Manado.

\section{DAFTAR PUSTAKA}

[1] Ayu Nawang Retno Ning Tyas. Politeknik Negeri Surabaya. "Analisa Penyebaran Penyakit Demam Berdarah Di Surabaya Menggunakan Cellular Automata".

[2] Annisa, Abdul Basid (2010). Jurusan FMIPA Fisika Universitas Negeri Malang. "Simulasi Tumbukan Partikel Gas Ideal dengan Model Cellular Automata"

[3] Averill M. Law w. David Kelton. Simulation Modeling \& Analysis, International Edition 1991.

[4] Diannita Kartikasari. Jurusan Informatika Universitas Sebelas Maret, "Pembuatan Peta Data Prediksi Penderita Penyakit DBD di Kota Surakarta Dengan Metode SusceptibleInfected-Removed (SIR)", vol.4, no.1, Juni. 2015.

[5] Dr. Eng. Steven Ray Sentinuwo, ST,,MTI dan Oktavian Abraham Lantang, ST.,MTI, "Pemodelan dan Simulasi Arus Kendaraan Pada Persimpangan Bundaran Di kota Manado untuk Analisa Kepadatan Lalu Lintas dengan menggunakan model Cellular Automata". April 2015

[6] Hazliansyah. (2015, Januari.29) Wabah Demam Berdarah di kota Manado [Online].Available http://www.republika.co.id/berita/nasional/d aerah/15/01/29/nixkr8-manado-kotatertinggi-kasus-dbd-di-sulut.

[7] Library Terra.js [Online]. Available : http://rileyjshaw.com/terra/.

[8] Noya. (2015, Januari, 21) Waspada Demam Berdarah di kota Manado [Online]. Available : http://dinkes.manadokota.go.id/berita-158waspada-demam-berdarah-dengue.html.

[9] Syopiansyah Jaya Putra. Fakultas Sains \& Teknologi, "Algoritama Cellular Automata (CA) dan Backtracking untuk Simulasi Pencarian jalan pada Maze", vol.6, no.2, Oktober.2008.

[10] Stephen Wolfram. Statistical Mechanics of Cellular Automata. Rev mod Phys.55,601 (1983). 
[11] Widjonarkoa. Universitas Diponegoro, "Pola Keruangan Penyakit Menular (DBD) Kota Semarang", vol.1, no.2, pp.114-124, 2014.

[12] William Dave Weno "Pemodelan dan Simulasi Pedestarian Untuk Evakuasi Bencana Pada Kawasan Boulevard Manado Menggunakan Model Cellular Automata". Oktober 2016.

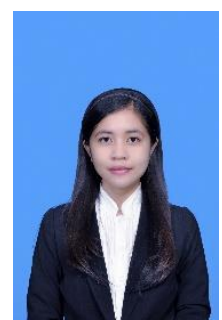

Sekilas dari penulis dengan nama lengkap Olivia Hasan, lahir di Manado, Provinsi Sulawesi Utara. Anak Tunggal. Dengan pendidikan pertama di Sekolah Dasar SD Negeri 42 Manado. Setelah itu melanjutkan ke Sekolah Menengah Pertama SMP Negeri 1 Manado. Kemudian melanjutkan ke Sekolah Menengah Atas SMA Negeri 1 Manado. Setelah itu Pada tahun 2011 melanjutkan ke Perguruan Tinggi di Universitas Sam Ratulangi dengan mengambil Jurusan Teknik Informatika. Pada Tahun 2015 bulan Juni, penulis membuat Skripsi demi memenuhi syarat Sarjana (S1) dengan penelitian berjudul Pemodelan dan Simulasi Penyebaran penyakit Demam Berdarah Dengue (DBD) dengan Menggunakan Model Cellular Automata yang dibimbing oleh dua dosen pembimbing yaitu Dr. Eng Steven R. Sentinuwo, ST., MTI dan Alwin M. Sambul, ST., M.Eng,Ph.D. Sehingga pada tanggal 31 Januari 2017 penulis resmi lulus di Teknik Informatika Universitas Sam Ratulangi Manado menyandang gelar sarjana komputer dengan predikat sangat memuaskan. 